ELORE (ISSN 1456-3010), vol. $16-2 / 2009$.

Julkaisija: Suomen Kansantietouden Tutkijain Seura ry.

[http://www.elore.fi/arkisto/2_09/kirjallisuus_leppalahti_2_09.pdf]

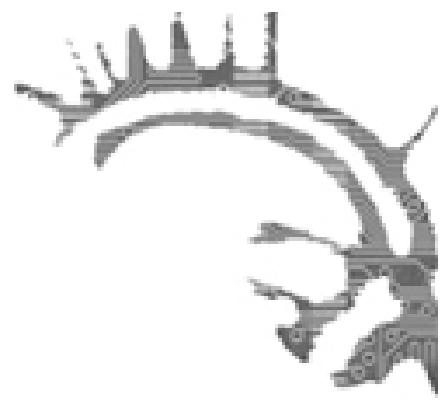

\title{
KIRJA-ARVIO:
}

\section{EsITYKsiä KaleVAlasta}

Gene 2009: Kullervo. Helsinki: Like Kustannus. 100 sivua (ei sivunumerointia). Jussila, Raimo 2009: Kalevalan sanakirja. Helsinki: Otava. 519 sivua.

Mikekola, Inkeri 2009: Kalevala yleiskielelle käännettynä. Nakekila: Sanasiivet. 328 sivua.

Pottonen, Risto 2009: Kalevala suomeksi. Helsinki: Books on Demand GmbH. 500 sivua.

\section{$\underline{\text { Merja Leppälahti }}$}

Kansalliseepoksemme Kalevala on ilmestymisestään lähtien innoittanut kuva- ja sanataiteilijoita sekä säveltäiıä. Alkuvaiheissaan Kalevala toimi erityisesti kansallishenkisen tuotannon inspiroijana. Toinen erityinen Kalevalaan kohdistunut kiinnostuksen aalto nousi 1960- ja 1970-luvulla, jolloin Kalevalan ainekset saivat realistisempia, arkeen kiinnittyviä sävyjä. Nyt 2000-luvulla Kalevala on taas ollut kovasti esillä, varsinkin kaunokirjallisuudessa on nähtävissä suorastaan yllättävän paljon laajoja tai suppeampia viittauksia Kalevalaan. Lähestymistavat ovat jälleen uudet: kansalliseepoksella voi jo leikitellä, ja sitä voi käsitellä huumorilla, toisaalta esille ovat nousseet Kalevalan sisältämät fantasia-ainekset.

1990-luvun lopulta lähtien Kalevalaa on myös kirjoitettu uudelleen pyrkimyksenä saattaa Kalevalan sisältö nykylukijalle helpommin avautuvaan muotoon. Varhaisia esimerkkejä vuodelta 1999 ovat Kai Niemisen Kalevala 1999, jossa Kalevalan tapahtumat ovat saaneet suorasanaisen muodon ja Matti Lehmosen Kalevala savon kielellä, jossa kirjoittaja "laettoo laalut uutee' uskoo / savonkielelle somalle" (Lehmonen 1999, 9). Näiden teosten jälkeen Kalevalaa tai sen osia on muokattu nykysuomelle tai jollekin suomen kielen murteelle useita kertoja, esimerkiksi Aulis Rintala on julkaissut teokset Kullervo pohojalaanen (2000), Kalevala nykysuomeksi (2006) ja Kalevala eteläpohjalaisella murteella (2008). Elma Kleemola on muokannut osan Kalevalasta Laitilan murteelle teoksessa Kalevalaa laitla murttel (2003). Petteri Hakkaraisen Vänämöinen, vanhana syntynyt (2004) puolestaan tiivistää Väinämöisen elämänvaiheet urbaanille suomenkielelle. 


\title{
MERJA LEPPÄLAHTI
}

Esikuvia Kalevalan uudelle käsittelylle siis on runsaasti olemassa.

Vuosi 2009 on Uuden Kalevalan 160-vuotisjuhlavuosi, ja tämän juhlavuoden merkeissä Kalevala on jälleen ollut erityisen paljon esillä. Vuonna 2009 ilmestyneitä Kalevalateoksia ovat Risto Pottosen Kalevala suomeksi, Inkeri Mikkolan Kalevala yleiskielelle käännettynä, Genen Kullervo ja Raimo Jussilan Kalevalan sanakirja. Nämä eivät edes ole ainoat, vaan vuoden 2009 aikana on ilmestynyt vielä useita muitakin vahvasti Kalevalaan kiinnittyviä teoksia.

\section{KALEVALAA UUDELLA KIELELLÄ}

Risto Pottosen Kalevala suomeksi ja Inkeri Mikkolan Kalevala yleiskielelle käännettynä ovat molemmat vuonna 2009 ilmestyneitä Kalevalan yleiskielisiä versioita. Kummassakin on mukana koko Kalevala. Risto Pottosen Kalevala suomeksi pyrkii tekemään Kalevalan sisältöä nykysuomalaiselle ymmärrettävämmäksi muuttamalla vieraita sanoja tutummiksi ja metaforisia ilmauksia selkokielisemmiksi. Pottonen ei ole kuitenkaan tyytynyt pelkästään suomentamaan ja yksinkertaistamaan vieraita ilmauksia, vaan hän on kirjoittanut koko Kalevalan uudelleen virke virkkeeltä. Pottosen uudisteksti on lisäksi jaettu säkeisiin ja säkeet numeroitu Kalevalan mukaisesti, mikä tekee vertailun alkuperäiseen hyvin helpoksi, mikäli sellaista haluaa tehdä.

Vuoden 1849 Kalevalassa kerrotaan, miten Untamo myy Kullervon Ilmariselle tämän osoittauduttua kaikkeen työhön kelpaamattomaksi:

\author{
Minpä seppo tuosta antoi? \\ Äijän seppo tuosta antoi: \\ kaksi kattilarania, \\ kolme koukun puoliskoa, \\ viisi viikatekulua, \\ kuusi kuokan kuolioa \\ miehestä mitättömästä, \\ orjasta epäpäöstä. (Kalevala 31:368-375.)
}

Tämän Pottonen on kirjoittanut uuteen muotoon:

Mitä seppä orjasta maksoi? Ei paljoa, vain tämän verran:

kaksi kuhmuista kattilaa, kolme padansangan puolikasta, viisi vanhaa viikatetta, kuusi kulunutta kuokkaa.

Se oli hinta surkeasta miehestä, kelvottomasta orjasta. (Pottonen 2009, 312.)

Nykykielisistä ilmauksista huolimatta Pottonen ei ole muuttanut tekstiä aivan suorasanaiseen muotoon vaan runollinen tuntu ja poljento ovat säilyneet. Tekstissä on paikoin sointi, jota tekisi mieli sanoa jopa raamatulliseksi. Kalevalamittaa Pottonen ei kuitenkaan juuri tekstissään käytä. Paikoin Pottonen on tarkoituksessa tai vahingossa tehnyt sisältöön pieniä muutoksia, esimerkiksi Kalevalan säkeessä 32:89 oleva "Mielikki, 


\section{ESITYKSIÄ KALEVALASTA}

metsän miniä" on muuttunut muotoon "Mielikki Metsän puoliso" (KS, 314), mikä johtunee tunnetummasta säkeestä "Mielikki metsän emäntä", joka esiintyy yleisesti kansanrunoudessa ja monessa kohtaa Kalevalaakin (14:45, 32:241 ja 46:477).

Inkeri Mikkola on myös teoksessaan Kalevala yleiskielelle käännettynä kääntänyt vieraita sanoja tutummiksi mutta pyrkinyt säilyttämään tekstissä myös kalevalamitan. Mikkola on ottanut mukaan paljon Kalevalan säkeitä aivan sellaisenaan, vain outoja sanoja hän on kääntänyt nykykieliseen muotoon. Muutoksissakin hän on säilyttänyt tekstin kalevalamitassa aina kun se on ollut mahdollista. Hän onkin todennut halunneensa saada aikaan aidontuntuisen Kalevalan, jossa on tallessa kaunis kieli, kalevalamitta sekä alku- ja keskisoinnut, mutta joka kuitenkin avautuu nykylukijalle "merkillisen ymmärrettävänä”. (Mikkola 2009, 5.)

Kullervosta maksetun hinnan Mikkola on muotoillut näin:

Mitä seppä tuosta antoi? Paljon seppä tuosta antoi:

kaksi kattilakulua, kolme koukun puoliskoa,

viisi viikatekulua, kuusi kuokkaa kelvotonta

miehestä mitättömästä, kelvottomasta pojasta. (Mikkola 2009, 220.)

Mikkolan Kalevala-versio on siten kauttaaltaan mahdollisimman kevyesti muokattu, kun taas Pottonen on tehnyt suurempia muutoksia ja paikoin ehkä käyttänyt hiukan enemmän taiteilijan vapauttakin. Mikkolan teoksessa on esipuheen lisäksi pelkästään Kalevala-teksti, jota hän kertoo kirjoittaneensa noin kaksi vuotta (Mikkola 2009, 5). Risto Pottonen on laatinut omaa teostaan yli kymmenen vuotta (BoD 2009). Pottosen versiossa on varsinaisen tekstin lisäksi myös selitysosio, jossa kirjoittaja avaa lyhyesti kunkin runon sisältöä ja alkuperää, sekä hakemisto. Sekä Pottosen että Mikkolan teoksilla on omat ansionsa, eikä niitä voi asettaa paremmuusjärjestykseen. Molemmissa on kaunista ja sujuvaa suomen kieltä, jota lukee ilokseen. Kummankin teoksen avulla on siten mahdollista tutustua Kalevalan sisältöön ilman selittävää sanakirjaa.

\section{KaLEVALAN SANOJA}

Raimo Jussilan Kalevalan sanakirja on tavallaan eräs versio nykykielisestä Kalevalasta, vaikka siinä Kalevalan sanat on luetteloitu aakkosjärjestykseen eikä siten, miten ne esiintyvät alkuperäisessä tekstissä. Jussila on halunnut keskittyä pelkästään Kalevalan sanastoon nimenomaan kalevalaisessa kontekstissa viittaamatta juuri Kalevalan ulkopuolelle. Tällaisena teos palvelee nimenomaan sellaista Kalevalan lukijaa, joka haluaa lukiessaan vain saada selville oudolta vaikuttavan sanan merkityksen eikä halua upota pitkällisiin selityksiin. Jussila viittaa vuonna 1949 julkaistuun Aimo Turusen laatimaan Kalevalan sanakirjaan ja sen uudistettuun laitokseen Kalevalan sanat ja niiden taustat (1979) teoksina, joista saa lisätietoja sanojen etymologiasta ja muusta taustatiedosta, jos niistä on kiinnostunut. Kirjan esipuheessa Jussila kuvaa sanakirjansa koostamistyötä taulukointeineen sekä tarjoaa myös hyvin tiiviin tietopaketin Kalevalan syntyvaiheista ja Elias Lönnrotin toiminnasta Kalevalan koostamisessa. 


\section{MERJA LePPÄLAHTI}

Kun Turusen sanakirja on ollut käytössä vuosikymmenien ajan ja toiminut hyvin, tarvitaanko uutta sanakirjaa? Jussilan teos ei varsinaisesti tuo Kalevalan sanakirjoihin kovin paljon uutta, oikeastaan päinvastoin, sillä hän on tarkoituksellisesti jättänyt sanojen selityksistä pois paljon sellaisia taustatietoja ja lisäselvitystä, mitä Turusen sanakirjassa on. Jussilan sanakirja onkin tarkoitettu niin sanotulle "tavalliselle lukijalle", joka ei tarvitse perinpohjaisia selityksiä eikä ehkä ole niistä kiinnostunutkaan, vaan haluaa ainoastaan tietää Kalevalassa esiintyvän sanan merkityksen. Tämä sanakirja kuuluu siten sijoittaa käden ulottuville Kalevalaa luettaessa. Uusi teos on toki myös helpommin saatavilla kuin kymmeniä vuosia sitten ilmestynyt; nykyäänhän kirjat siirtyvät tavallisesti alennusmyyntikoreihin ja poistomyyntiin jo muutaman vuoden ikäisinä.

Jussila on laatinut sanakirjansa luetteloimalla kaikki Kalevalassa esiintyvät sanat ja aakkostamalla näin saadut 8447 sanaa selityksineen. Kuten Turunen, myös Jussila on lukijaystävällisesti ottanut erillisiksi hakusanoikseen myös sellaiset taivutusmuodot, joita nykylukija ei välttämättä ymmärrä. Esimerkiksi sana silma, joka ei itsestään selvästi avaudu, selitetään seuraavasti: "sinua (sinä-sanan partitiivi)" (s. 359). Tämän jälkeen on esimerkki Kalevalan tekstistä "siellä silma lauletahan". Uutta Jussilan teoksessa on sanojen esiintymisfrekvenssien ilmoittaminen. Kunkin sanan kohdalla on ensimmäiseksi suluissa esitetty sanan esiintymisen lukumäärä, joten on helppo nähdä, onko kysymyksessä Kalevalassa yleisesti esiintyvä sana vai ehkä kertaluonteinen ilmiö. Esimerkiksi silma esiintyy Jussilan mukaan Kalevalassa kahdesti.

\section{KaleValaA KUVITETTUNA}

Kullervon tarina on Sammon ohella kuulunut Kalevalan suosituimpiin aihepiireihin näytelmissä, musiikissa ja kuvataiteessa. Genen Kullervo on sarjakuva, joka kertoo Kalevalaan sisältyvän Kullervon tarinan, käsittäen Kalevalan runot 31-36. Genen kuvissa Kullervo ja muut toimijat ovat kyborgimaisia olentoja, joiden alastomiin vartaloihin kiinnittyy keinotekoisia osia. Puhekuplien vuorosanat liikkuvat huumeiden ja rikollisuuden maailmassa. Kalevalan runomuotoiset alkuperäistekstit kulkevat kuitenkin myös koko ajan mukana joko erillisissä tekstilaatikoissa tai piirrosten taustalla.

Kullervon elämänvaiheet seuraavat tarkasti Kalevalan kuvausta. Paimeneen lähetettävä Kullervo saa runsaasti ohjeita Ilmarisen emännältä. Tämä on toteutettu siten, että kirjan neljä sivua on täynnä Kalevalan tekstiä: Ilmarisen emännän lukemat karjan suojeluloitsut. Tekstin päällä kuvituksessa kulkevat emännän vuorosanat, jotka menevät myrtyneen näköisen Kullervon toisesta korvasta sisään ja toisesta ulos: "etkä vaa maleksi niitten perässä - - muista kans juottaa ne jossain välissä ja pälä pälä - - " kunnes Kullervo karjaisee: "Turpa kiinni!" ja lähtee synkkäilmeisenä lehmien kanssa matkaan. Eväänä hänellä ei ole leipää vaan huumeruisku, jonka Ilmarisen emäntä on hänelle täyttänyt varoittaen piikittämästä ennen kuin lehmät ovat metsässä. Paha emäntä on kuitenkin tukkinut ruiskun, jonka rikkoutuessa Kullervo menettää ainoan esineen, joka hänellä oli muistona isästään. Kullervon tarina etenee kuten Kalevalassa: hän kostaa emännälle, viettelee sisarensa ja kuolee lopulta oman kätensä kautta. Rinnakkain kulkevien Kalevalan tekstien ja Genen kuvien ja puhekuplien välillä on 


\section{ESITYKSIÄ KALEVALASTA}

kiinnostava jännite; paikoin vastaan tulee todella hauskoja oivalluksia.

Sarjakuvinakin Kalevalaa on esitetty jo aikaisemmin, laajimmin Kristian Huitulan albumeissa Kalevala ja Kalevala II, joissa alkuperäiseen Kalevalan tekstiin on liitetty dramaattinen, goottihenkinen kuvitus. Sarjakuvamuotoisia Kalevaloja voi pitää nykyaikaisena jatkumona kuvitetuille Kalevala-versioille, joiden klassikko on Akseli Gallen-Kallelan Koru-Kalevala (1922). Monet muutkin taiteilijat ovat innostuneet Kalevalasta siinä määrin, että ovat kuvittaneet koko teoksen. Esimerkiksi Jukka Salminen (1947-2006) teki Kalevalan (1998) kuvituksen lisäksi useita Kalevala-aiheisia veistoksia. Jos täsmälleen samaan Kalevalan tekstiin yhdistetään erilainen kuvitus, kysymyksessä on silti ilman muuta sama eepos. Esimerkiksi Akseli Gallen-Kallelan tai Jukka Salmisen kuvittamat Kalevalat ovat kuitenkin tyyliltään hyvin erilaisia; teosten lehteily tuottaa heti vaikutelman kahdesta selvästi erilaisesta Kalevala-tulkinnasta. Entä kun Kalevalasta tulee sarjakuva? Kristian Huitulan Kalevala-sarjakuvissa ei oikeastaan ole mitään sellaista, mikä sotisi alkuperäisen Kalevalan henkeä vastaan, kun taas Gene Kurkijärven kuvissa Kullervo on selvästi erilainen olento kuin Kalevalan Kullervo. Tekstin tasolla tapahtumat ovat kuitenkin aivan samat, jopa samoin sanoin kerrottuna. Kuvat ja puhekuplat vain tuovat aiheeseen jotain lisää.

Nimenomaan Kalevalan juhlavuoden tuote on Taiteilijoiden Kalevala, jossa Kalevalan tekstiä kuvittavat nykytaiteilijoiden työt. Kalevalaseuran kymmeneltä nykysäveltäjältä ja kuvataiteilijalta tilaamat teokset on tarjottu yleisölle myös kirjan ulkopuolella, Helsingissä Ateneumissa 27.2.-9.8.2009 sekä Turun taidemuseossa 25.9.-10.1.2010. Myös sävellystyöt kuuluvat Taiteilijoiden Kalevalaan, vaikka ne eivät soi sivuja lehteillessä, vaan ne on liitetty mukaan kahtena CD:nä. Lisäksi kirjan mukana on DVD-levy, jolle on tallennettu videotaideteos.

\section{Kalevalan moneus}

Tässä käsitellyt Kalevala-esitykset ovat selvästi Kalevalan hypertekstejä (Genette 1997, 5) eli tekstejä, joiden olemassaolo perustuu niin vahvasti Kalevalaan, että ilman alkuperäistä Kalevalaa nämäkään teokset eivät olisi voineet syntyä. Millainen on sitten raja Kalevalan ja muiden tekstien välillä? Jo Elias Lönnrot laati aikanaan useampia versioita Kalevalasta; näistä vuoden 1849 Kalevala on nykyään "se oikea" ja toiset jotakin muuta. Mutta ovatko nykykieliset tai murteelliset Kalevalan esitykset saman teoksen uusia muunnoksia vai aivan eri teoksia? Ovatko ne verrattavissa käännöksiin muille kielille? Mikä on tekijän osuus? Nämä kysymykset kytkeytyvät keskusteluun teoksesta ja tekijyydestä laajemminkin, eikä niihin ole yksiselitteistä vastausta.

Entä mikä sitten saa kirjoittajat tarttumaan yhä uudelleen juuri Kalevalaan? Tietenkin juhlavuosi on omiaan herättämään myös kirjoittajien kiinnostusta, mutta se ei yksistään selitä Kalevala-teosten runsautta. Ainakin osa näistä julkaisuista on varmasti aivan tarkoituksellisesti ajoitettu juhlavuodelle, mutta on muistettava, että Kalevalan tekstejä on kirjoitettu uudestaan jo vuosia. Kalevala-julkaisut eivät tavallisesti ole mitään myyntimenestyksiä, monet niistä ovat omakustanteita tai vastaavia. Ainakaan taloudellisesti ei Kalevala siten kuulu kannattavimpiin valintoihin. On pakko uskoa, että 


\section{MERJA LePPÄLAHTI}

Kalevala kokonaisuutena merkitsee yhä ainakin meille suomalaisille jotain niin erityistä, että tuntuu tarpeelliselta löytää keinoja saada Kalevala yhä uusien lukijoiden saataville ja herättää näiden kiinnostus. Kalevalan varhaisvaiheissa kaikki siihen kohdistuva kirjoittelu, kriittinenkin, oli omiaan vahvistamaan sen asemaa kansalliseepoksena. (Knuuttila 2008, 387.) Vastaavasti myös nykyään jokainen uusi Kalevala-teksti vahvistaa Kalevalan arvoa ja erityisasemaa. Kalevalan yleisen arvostuksen lisäksi myös Kalevalan sisällössä täytyy olla sellaisia aineksia, jotka jollakin tavalla puhuttelevat edelleen. Kalevala on julkaistu 1800-luvulla, ja kansanrunot sisällön taustalla ovat sitäkin vanhempia. Silti Väinämöisen, Kullervon, Ilmarisen, Lemminkäisen tai Ainon kohtaloissa jokin koskettaa myös nykylukijaa.

\section{KirJallisuUs}

BoD 2009: Kalevala suomeksi avaa lukijalle kansalliseepoksemme salat ensi kertaa nykyykielellä [online]. <http://www.bod.fi/ltiedote-29012009.html> [26.10.2009.]

GENETTE, GERARD 1997: Palimpsests. Literature in the Second Degree. Lincoln: University of Nebraska Press.

HAKKARAINEN, PETTERI 2004: Väinämö̈nen, vanbana syntynyt. Helsinki: Johnny Kniga.

HUITULA, KRISTIAN 1998: Kalevala. Omakustanne.

-2000: Kalevala II. Omakustanne.

Kalevala 1922. Porvoo: WSOY. [Kuvitus- ja painatustyön ohjannut Akseli Gallen-

Kallela, kieliasun valvojana toiminut Jalo Kalima avustajanaan O. Manninen.]

Kalevala 1998. Kuvittanut Jukka Salminen. Helsinki: Like.

KLEEMOLA, ELMA 2003: Kalevalaa laitla murttel. Laitila: Kalevanpojan Kulttuuriseura Untamala ry.

KNUUTTILA, SEPPO 2008: Muita kalevaloita - kuvitelmia ja kilpailijoita. - Piela, Ulla, Knuuttila Seppo ja Laaksonen, Pekka (toim.): Kalevalan kulttuuribistoria. Helsinki: SKS.

LEHMONEN, MATTTI 1999: Kalevala savon kielelläa. Jyväskylä: Atena.

NIEMINEN, KAI 1999: Kalevala 1999. Helsinki: SKS.

PIELA, ULLA 2009 (toim.): Taiteilijoiden Kalevala. Helsinki: SKS.

RINTALA, AULIS 2000: Kullervo pohojalaanen. Jyväskylä: Atena.

- 2006: Kalevala nykysuomeksi. Tampere: Pilot-kustannus.

- 2008: Kalevala eteläpohjalaisella murteella. Tampere: Lumo.

TURUNEN, AIMO 1949: Kalevalan sanakirja. Helsinki: SKS.

-1979: Kalevalan sanatja niiden taustat. Joensuu: Karjalaisen kulttuurin edistämissäätiö.

Filosofian lisensiaatti Merja Leppälahti on folkloristiikan jatko-opiskelija Turun yliopistossa. 